\section{NU UNA Kastamonu Eğitim Dergisi Kastamonu Education Journal}

Kasım 2019 Cilt:27 Sayı:6

kefdergi.kastamonu.edu.tr
Başvuru Tarihi/Received: 03.12.2018

Kabul Tarihi/Accepted: 21.01.2019

DOI: 10.24106/kefdergi.3454

\title{
Sınıf Öğretmeni Adaylarının Kesir ve Kesir Öğretim Bilgilerinin
} İncelenmesi

\section{Examining Pre-service Primary School Teachers Knowledge About Fractions and Fractional Teaching Knowledge ${ }^{1}$}

\section{Öz}

\author{
Serap AKBABA DAĞ ${ }^{2}$, Özlem DOĞAN TEMUR ${ }^{3}$
}

Bu çalışmanın amacı sınıf öğretmeni adaylarının kesir ve kesir öğretim bilgileri nasıldır sorusuna yanıt aramaktır. Çalışma bir devlet üniversitesinin Sınıf Öğretmenliği Programına devam eden 7 son sınıf öğrencisiyle yürütülmüştür. Çalışmanın verileri Kesir öğretim bilgisi soruları (KÖBS) ile toplanmıştır. KÖBS; iki çoktan seçmeli, bir eşleştirme ve beş açık uçlu sorudan oluşmakta olup, toplamda ikişer şıklı sekiz soruyu içermektedir. Sorular; kesir bilgisi, kesirlerle işlemler ve öğrenci hataları giderilmesi, kesirlerde karşılaştırmanın öğretimi ve olası öğrenci düşüncelerinin tahmini, kesir işlemleri ile ilgili problem kurma ve çözümü modelleme konularını kapsamaktadır. Soruların hazırlanmasında mevcut literatür taranmış ve soruların çoğunluğu benzer çalışmalarda kullanılan problemlerin uyarlanmasından oluşturulmuştur. Veri toplama aracından elde edilen veriler nitel veri olup; analizinde betimsel analiz ve içerik analizi yaklaşımı kullanılmıştır. Elde edilen verilerin analizinden; öğretmen adaylarının kesirlerle işlemler ve problem kurma, kesrin farklı anlamları, işlemsel ve kavramsal sorulara uygun yanıtlar verebilme, öğrencilerin kesirler konusundaki muhtemel düşüncelerini tahmin edebilme noktasında sıkıntılar yaşadığı sonuçlarına ulaşıımıştr.

Anahtar Kelimeler: kesirler, kesir öğretim bilgisi, sınıf öğretmeni adayı.

\section{Abstract}

The aim of this study is to answer to the question of how the pre-service primary school teachers knowledge about fractions and fractional teaching knowledge. The study was carried out with 7 final year students attending the Primary School Teaching Program of a public university. The data of the study were collected by fractional teaching knowledge questions. It consists of two multiple choice, one pairing and five open-ended questions, totaling eight questions in total. Questions includes fractional information, processing of fractions and the elimination of student errors, teaching of comparison in fractions and estimation of possible student thoughts, problem posing and modeling of fractional problems. In the preparation of the questions, the current literature was reviewed and the majority of the questions were formed from the adaptation of the problems used in similar studies. The data obtained from the data collection tool are qualitative data; Descriptive analysis and content analysis approach were used in the analysis. From the analysis of the data obtained; it is concluded that pre-service teachers; operations with fractions and problem posing, different meanings of fraction, appropriate answers to operational and conceptual questions, and difficulty in to be able to predict the possible thoughts of the students on fractions.

Keywords: fractions, fractional teaching knowledge, pre-service primary school teachers

1 Bu çalışma, birinci yazarın ikinci yazar danışmanlığında hazırladığı doktora tezinden üretilmiştir.

2 Kütahya Dumlupınar Üniversitesi, Eğitim Fakültesi, Temel Eğitim Bölümü,Kütahya, Türkiye; https://orcid.org/0000-0003-2188-563X

3 Kütahya Dumlupınar Üniversitesi, Eğitim Fakültesi, Temel Eğitim Bölümü, Kütahya, Türkiye; https://orcid.org/0000-0002-1877-0973

Atıf / Citation: Akbaba Dağ, S. \& Doğan Temur, Ö. (2019). Sınıf öğretmeni adaylarının kesir ve kesir öğretim bilgilerinin incelenmesi .Kastamonu Education Journal, 27(6), 2569-2581. doi:10.24106/kefdergi.3454 


\section{Extended Abstract}

The subject of fractions is one of the most challenging subjects of the primary school mathematics curriculum, rich in content, complex, learning and teaching. In order to teach an effective fraction teaching, both teachers' and pre-service teachers' fractions and fractional teaching knowledge should be built on solid foundations. In this context, this research aims to seek answers to the question of how the prospective primary school teachers are fractions and fractional teaching knowledge.

The study was conducted with the Department of Primary School Education of final year students of a state university. Seven pre-service primary school teachers participated in the study. Pre-service teachers were coded as ÖA1, ÖA2, ÖA3, ÖA4, ÖA5, ÖA6, ÖA7. The research data were collected by means of the Fraction Teaching Knowledge Questionnaire Form (SBSF). The questions of the fraction teaching knowledge include a total of eight questions, each of which consists of two multiple choice, one pairing and five open-ended questions. Questions include topics such as fractional knowledge, operations with fractions and elimination of student errors related to operations, teaching of comparison in fractions and the estimation of potential students thinking, problem posing about fraction operations and modeling the solution. During the preparation of the questions, the current literature was reviewed and the majority of the questions were created by adapting the problems used in similar studies. In the analysis of data, descriptive analysis and content analysis approach were used.

The first and second questions in the KÖBSF are the ones that evaluate the status of pre-service teachers knowing the different meanings of a fraction. From these questions, it was found that pre-service teachers were only able to make an accurate assessment about the ratio meaning of the fraction, otherwise they had difficulty in identifying the meaning of the part and whole and peering status in a sentence. In the third question, which includes a student description of the addition with fractions, it was seen that none of the pre-service teachers explained the key concepts required for the correct solution. The fourth and fifth questions relate to the comparison and listing of fractions. From these questions, it was found that pre-service teachers have difficulties about based on the theoretical knowledge of the pre-service teachers, predicting the possible thoughts of students and what students can do about fractions and in which order the fractional instruction should be done. The sixth question relates to the modeling of the multiplication with fractions; none of the pre-service teachers were able to model the multiplication with fractions and all of the pre-service teachers confused the division process by multiplication. The seventh question is aimed at identifying student misconceptions about operations with fractions. All of the pre-service teachers gave correct answers to this question and made appropriate explanations. The last question is about posing problem about fraction operations and modeling of operations. Findings from this problem show that pre-service teachers have not difficulty in following procedural procedures on fractional operations, but they experience conceptual difficulties.

Results of the research show that pre-service teachers have difficulties in operations with fractions and posing problem, in the different meanings of the fraction, in giving appropriate answers to procedural and conceptual questions, in predicting students' possible thoughts on fractions. 


\section{Giriş}

Kesirler konusu ilkokul matematik programının en zengin, karmaşık (Alacacı, 2010), öğrenilmesi (Doğan Temur, 2011; Haseman, 1981) ve öğretiminde (Behr, Harel, Post ve Lesh, 1992; Cramer, Post, ve delMas, 2002; Moss ve Case 1999) zorlanılan konularından biri olmakla birlikte; literatürde kesir öğretimi ve öğretmen bilgisi konularında araştrmalara (Işık, Kar, Işık ve Güler, 2012; Özmantar ve Bingölbali, 2009; Toluk Uçar, 2011; Ward,2009) sık rastlanılmaktadır. Kesir öğretimine ilişkin yapılan çalışmalarda öğretmenlerin (Gökkurt, Soylu ve Demir, 2015; Kar ve Işık, 2015) ve öğretmen adaylarının (Gökkurt, Şahin, Soylu ve Soylu, 2013; Işık, 2011) eksik bilgilere sahip oldukları aynı zamanda öğrenci hataları ve öğrencilerin sahip olduğu kavram yanılgılarını açıklamada yetersiz kaldıkları görülmüştür. Öğretmenlerin ve öğrencilerin yaşadığı bu zorlukların üstesinden gelebilmek için ilkokuldan öğretmen eğitimine kadarki süreçte kesir kavramı ve öğretiminin nasıl gerçekleştirileceği sağlam temeller üzerine kurulmalıdır. Bu temeller ilk önce kesrin değişik anlamlarının öğrencide somutlaştıılması ile gerçekleşir (Doğan Temur, 2011). Çeşitli kaynaklarda (Altun, 2005; Olkun ve Toluk 2006; Van de Walle, 2013) verilen bu anlamlar parça-bütün, bölüm, oran, işlemci ve ölçme olarak özetlenebilir. Kesir öğretiminde parçalara ayırma, adlandırma, sayma, sayısal semboller kullanma, görsel modeller kullanma ve modellerin çeşitlenmesi şeklinde alt basamaklı bir sıra (Doğan Temur, 2011) izlenir. Bu sıranın son iki basamağı olan model kullanımı ve çeşitlemesinin kesir kavramının anlaşımasındaki önemi çeşitli çalışmalarda da (Cramer ve Henry, 2002; Siebert ve Gaskin, 2006) vurgulanmıştr. Kesirlerin öğretiminde alan, küme, uzunluk ve hacim modelleri kullanılmaktadır. Farkı modeller, öğrenme için farklı fırsatlar sunar. Uygun ve çok çeşitli modellerin kullanımı öğrencilerin ve öğretmenlerin kesir anlayışlarını geliştirir. Örneğin bir alan modeli öğrencilere bir bütünün parçalarını görselleştirmede yardım ederken, doğrusal bir model herhangi iki kesir arasında her zaman başka bir kesrin bulunabileceğini gösterir (Van de Walle, 2013).

Kesirlerin öğretiminde farklı yöntemler uygulanmakla birlikte genelde kesrin kavramsal olarak ne anlama geldiğinden çok kesir işlemleri için gerekli olan algoritmaların öğretimi, başka bir deyişe kavramsal bilgiden çok işlemsel bilginin öğretimi yaygındır (Aksu, 1997). Kesirlerle ilgili olarak eğitim durumları belirlenirken öncelikle öğretmenlerin, öğrencilerinin sıklıkla yaşadıkları zorlukları ve kavram yanılgılarını iyi bilmeleri ve öğretimlerini bu yanılgıların giderilmesine yönelik tasarlamaları gerekmektedir. Yapılan çalışmalarda kesirlerde görülen en yaygın kavram yanılgıları ve zorluklar şöyle özetlenmektedir (Aksu, 1997; Alacacı, 2009; Başgün ve Ersoy, 2001; Haser ve Ubuz, 2001; Moss ve Case 1999):

- Kesrin sembolik gösteriminde a/b' nin tek bir sayı olarak algılanmasında güçlük çekilmesi,

- Kesir tanımı ile ilgili eş parçalara ayırma ile tanımlanmış kesirleri yazmada yaşanan zorluklar,

- Sayı doğrusu üzerinde basit, tam sayılı ve bileşik kesirlerin gösteriminde zorluklar,

- Kesirlerin ifade ettiği miktarın referans alınan bütüne bağlı olduğu düşüncesinin gelişmemesine bağlı yanılgılar,

- Kesirlerin karşılaştrııması ve sıralanmasında doğal sayıları sıralama ve karşılaştırma yöntemlerini kullanma,

- Kesirlerle toplama işleminde pay ve paydalarını ayrı ayrı toplayıp paya ve paydaya yazma,

- Tam sayılarda çarpma işleminin sonucu çarpılanlardan büyükse, kesirlerde sonucun çarpılandan küçük çıkabiliyor olmasını anlamakta yaşanan zorluklar ile

- Kesir konusu ile ilgili problem çözümü uygulamalarının anlaşılmasında yaşanan zorluklardır.

Yukarıda belirtilen ve benzer diğer yanılgıların sebepleri; günlük hayatta kesirlerin az kullanılması bu yüzden anlaşımasının doğal sayılardan daha zor olması ve yazımda gösterim biçimlerinin karmaşık olması, sayı doğrusunda kesirleri sıralamanın zor olması aynı zamanda kesir kavramını anlama üzerine değil kural ezberlemeye dayalı öğretim şeklinde ifade edilmiştir (Haseman, 1981).

Literatürde belirtilen yanılgıların üstesinden gelebilmeyi amaçlayan, illkokul 1-4 matematik öğretim programının rehberliğinde etkili bir kesir öğretimi için öğretmenlerin ve öğretmen adaylarının da kesir ve kesir öğretim bilgilerinin sağlam temeller üzerine oturmuş olması gerekir. Bahsedildiği üzere kesirler hem öğretiminde hem öğrenilmesinde güçlük çekilen konulardan biridir. Gelecekte öğretim programının asıl uygulayıcısı olacak öğretmen adaylarının hali hazırdaki kesir bilgilerinin ve bu konunun öğretimine ilişkin olarak kesir öğretim bilgilerinin tespit edilmesinin önemli olduğu düşünülmektedir. Bu bağlamda bu araştırmanın amacı sınıf öğretmeni adaylarının kesir ve kesir öğretim bilgileri nasıldır sorusuna yanıt aramaktır.

\section{Yöntem}

Sınıf öğretmeni adaylarının kesir ve kesir öğretim bilgilerinin belirlenmesinin amaçlandığı bu araştırmada durum çaıışması yöntemi kullanılmıştr. Temelde amaç öğretmen adaylarının kesir ve kesirleri öğretme bilgileriyle ilgili bir genellemeye ulaşmaktan çok her bir öğretmen adayının cevaplarını ayrıntılı incelemektir. Bu yöntemin avantajı özel bir konu 
ya da durum üzerinde yoğunlaşılabilmesine fırsat vermesidir (Çepni, 2012). Ayrıca çalışmada her bir öğretmen adayının kesir ve kesir öğretim bilgisi bir durumu temsil ettiği için çalışılan durumlar arası farklıııların incelenmesi açısından da çalışmanın yöntemine çoklu durum çalışması da denebilir (Çepni, 2012).

\section{Çalışma Grubu}

Bu araştırma bir devlet üniversitesinin Sınıf Öğretmenliği Programı son sınıf öğrencileriyle yürütülmüştür. Araştırmaya 7 sını öğretmeni adayı katılmıştır. Öğretmen adayları ÖA1, ÖA2, ÖA3, ÖA4,ÖA5, ÖA6, ÖA7 şeklinde kodlanmıştr.

\section{Veri toplanması ve analizi}

Araştırmanın verileri Kesir öğretim bilgisi soruları (KÖBS) formu aracılığı ile sınıf ortamında toplanmıştr. Katılımcılara soruları cevaplaması için bir saat süre verilmiştir. Formda yer alan kesir öğretim bilgisi soruları (KÖBS) iki çoktan seçmeli, bir eşleştirme ve beş açık uçlu sorudan oluşan, toplamda sekiz soruyu içermektedir. Sorular; kesir bilgisi, kesirlerle işlemler ve öğrenci hatalarının giderilmesi, kesirlerde karşılaştırmanın öğretimi ve olası öğrenci düşüncelerinin tahmini, kesir işlemleri ile ilgili problem kurma ve çözümü modelleme konularını kapsamaktadır. Soruların hazırlanmasında mevcut literatür taranmış ve sorular benzer çalışmalarda kullanılan problemlerin uyarlanmasından oluşturulmuştur (Akbaba Dağ, 2009; Özmantar ve Bingölbali, 2009; Ward ve Thomas, 2007). Uygulama öncesinde bir alan uzmanının görüşleri doğrultusunda gerekli düzenlemeler yapılarak soruların yapı ve kapsam geçerliği sağlanmaya çalışılmıştır. Bu veri toplama aracından elde edilen veriler nitel veri olup; analizinde betimsel analiz ve içerik analizi yaklaşımı kullanılmıştır. Bu yaklaşıma göre veriler araştırma sorularının ortaya koyduğu temalara göre düzenleneceği gibi görüşme ve gözlem süreçlerinde kullanılan sorular ya da boyutlar dikkate alınarak da sunulabilir (Yıldııı ve Şimşek, 2008). İçerik analizi, birbirine benzeyen verileri belirli literatürden ya da verilerden elde edilen kavramlar ve temalar çerçevesinde bir araya getirmek ve bunları okuyucunun anlayabileceği bir biçimde düzenleyerek yorumlamaktır. (Çepni, 2012). KÖBS sorularının her biri kesirler ve kesir öğretim bilgisini farklı açılardan belirlemeyi amaçladığı için verilerin analizinde her bir soru için sorunun içeriğine uygun olacak şekilde ayrı ayrı kod ve tema belirlenmiştir.

\section{Bulgular}

Soru 1: Aşağıda $\frac{3}{4}$ kesrinin farklı anlamları için örnek durumlar verilmiştir. Kesrin anlamları ile örnek durumları eşleştiriniz.

\begin{tabular}{|c|}
\hline Anlam \\
\hline Parça-Bütün \\
\hline Ölçme \\
\hline İslemci (operatör) \\
\hline Oran \\
\hline Bölme \\
\hline
\end{tabular}

\begin{tabular}{|l|}
\hline Örnek durum \\
\hline $\begin{array}{l}3 \text { pastayı } 4 \text { çocuk eşit şekilde paylaşırsa her çocuğun } \\
\text { aldığı pasta miktarıdır. }\end{array}$ \\
\hline $\begin{array}{l}\text { Bir pastanın } 4 \text { eş parçasından 3'ünü yiyen bir çocu- } \\
\text { ğun yediği pasta miktarıdır. }\end{array}$ \\
\hline $\begin{array}{l}\text { Bir pasta kutusundaki çilekli pastaların muzlu pasta- } \\
\text { lara oranının 3'e } 4 \text { olmasıdır. }\end{array}$ \\
\hline $\begin{array}{l}\text { Bir pastanın üçte birlik dilimlerinden } 2 \text { dilim yiyen bir } \\
\text { çocuğun yediği pasta miktarıdır. }\end{array}$ \\
\hline $\begin{array}{l}\text { Bir pastanede } 12 \text { pastanın üçte ikisinin satılması ile } \\
\text { satılan pasta miktarıdır. }\end{array}$ \\
\hline
\end{tabular}

Bu soru sağlam bir kesir kavramının temelinin kesrin değişik anlamlarının öğrencide somutlaştrılması ile gerçekleşeceği (Olkun ve Toluk, 2006) düşüncesinden yola çıkılmış, öğretimi gerçekleştirecek olan öğretmen adaylarının bu anlamları içeren örnek durumlar ile kendilerinde oluşturdukları anlamların birbirini karşılayıp karşılamadığını belirlemek için öğretmen adaylarına yöneltilmiştir. Öğretmen adaylarından beklenen doğru eşleştirme aşağıdaki gibi olmalıdır.

Bölme: 3 pastayı 4 çocuk eşit şekilde paylaşırsa her çocuğun aldığı pasta miktarıdır.

Parça-Bütün: Bir pastanın 4 eş parçasından 3'ünü yiyen bir çocuğun yediği pasta miktarıdır.

Oran: Bir pasta kutusundaki çilekli pastaların muzlu pastalara oranının 3'e 4 olmasıdır.

Ölçme: Bir pastanın dörtte birlik dilimlerinden 3 dilim yiyen bir çocuğun yediği pasta miktarıdır.

İşlemci(operatör): Bir pastanede 12 pastanın dörtte üçünün satılması ile satılan pasta miktarıdır. 
Tablo 1. Öğretmen Adaylarının Kesrin Anlamları İle Örnek Durum Eşleştirmeleri

\begin{tabular}{|c|c|}
\hline Öğretmen adayı & Örnek Durum Eşleştirmeleri \\
\hline \multirow{2}{*}{ ÖA1 } & Parça bütün anlamı ile bölme örnek durumunu, \\
\hline & Bölme anlamı yerine parça bütün örnek durumunu eşleştirmiş. \\
\hline ÖA2 & Kesrin tüm anlamları ile örnek durum eşleştirmeleri doğru. \\
\hline ÖA3 & $\begin{array}{l}\text { Kesrin tüm anlamları ile örnek durum eşleştirmeleri doğru. } \\
\text { Parça-bütün anlamı ile işlemci örnek durumunu, }\end{array}$ \\
\hline \multirow[t]{2}{*}{ ÖA4 } & İşlemci anlamı ile ölçme örnek durumunu, \\
\hline & $\begin{array}{l}\text { Ölçme anlamı ile parça bütün örnek durumunu eşleştirmiş. } \\
\text { Parça bütün anlamı ile ölçme örnek durumunu, }\end{array}$ \\
\hline ÖA5 & $\begin{array}{l}\text { Ölçme anlamı ile parça bütün örnek durumunu eşleştirmiş. } \\
\text { Parça bütün anlamı ile bölme örnek durumunu, }\end{array}$ \\
\hline ÖA6 & $\begin{array}{l}\text { Bölme anlamı yerine parça bütün örnek durumunu eşleştirmiş. } \\
\text { Parça bütün anlamı ile ölçme örnek durumunu, }\end{array}$ \\
\hline ÖA7 & Ölçme anlamı parça bütün örnek durumu eşleştirmiş. \\
\hline
\end{tabular}

Tablo 1' e bakıldığında öğretmen adaylarının tümünün sadece kesrin oran anlamı ilgili doğru eşleştirmeyi yaptığı, yedi öğretmen adayından sadece ikisinin (ÖA2,ÖA3) tüm anlamlar ile örnek durumları doğru eşleyebildiği görülmektedir. Bunun dışında iki öğretmen adayının ölçme anlamı ile parça bütün anlamı (ÖA5,ÖA7), iki öğretmen adayının parça-bütün, bölme anlamı (ÖA1,ÖA6) ve bir öğretmen adayının (ÖA4) ise kesrin parça-bütün, işlemci, ve ölçme anlamlarına karşıık gelen örnek durumları eşleme konusundaki hataları görülebilir.

Soru 2: Bir öğrenciden $\frac{2}{3}$ kesrinin şekil üzerinde gösterilmesi istenildiğinde öğrenci aşağıdaki şekli çizmiştir.

Öğrenci çizimi hakkında ne düşünüyorsunuz?

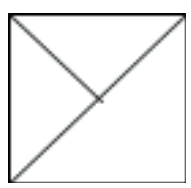

b. Yukarıdaki soruya verdiğiniz cevabın sebebini açıklayınız.

Kesir kavramının başlangıç noktası eş paylaştırma olduğundan öğretmen adaylarının bu soruya verdiği cevaplar önemlidir. Öğretmen adaylarının bu konuyla ilgili düzenleyecekleri öğrenme-öğretme etkinliklerinde ilk önce eş olma, bütünün eş parçalara ayrılması ve öğrencilerin bu konudaki olası kavrayışları hakkında bilgi sahibi olmaları gerekmektedir. Bu soruda yedi öğretmen adayından beklenen cevap; “ Öğrencinin cevabı yanlıştr. Çünkü öğrenci parçalarla ilgilenmekten çok parçaların sayısı ile ilgilenmektedir. Öğrenci belirtilen kesrin üç eş parçaya bölünmüş bir bütünün iki parçası anlamından, parçaların eş olması gerektiğini göz ardı etmektedir" şeklinde olmalıdır.

Öğretmen adaylarından ÖA1 hariç hepsi cevaplarında parça-bütün ilişkisi, eş parçalama kavramlarına vurgu yaparak; karenin eş parçalara ayrılmadığı bu yüzden öğrenci cevabının yanlış olduğunu belirtmişlerdir. Aşağıda öğretmen adaylarının örnek cevaplarında bazıları verilmiştir.

ÖA4: "Parçalar eş değildir. Büyüklükleri eşit olmalıdır. Kareyi bu şekilde üç eş parçaya bölmek doğru bir kesir oluşturmaz."

ÖA6: "Bu kesir öncelikle bir bütünün üç eşit parçaya ayrılıp 2 parçasının alınmasını gerektirir. Parçalarda eşitlik durumu olmadığı için yanlıştır. Ayrıca şekilde eşit bölünmediği gibi pay kısmını gösteren bir boyama da yoktur."

ÖA1 ise çizimin yanlış olduğunu belirtmiş fakat açıklamasında eş parçalamadan ziyade pay kısmında verilen parçaların taranmamasından dolayı yanlışlık olduğunu vurgulamıştır. ÖA1'in cevabı aşağıdaki gibidir.

ÖA1: Yanlıştır çünkü öğrenci kaçta kaç istendiği bölgeyi taramamıştır. Taraması gerekmekteydi."

Soru 3: . $\quad \frac{3}{5}+\frac{2}{3}=\frac{5}{8}$ işlemini öğrencilerinizden birinin defterinde görüp, öğrencinize nasıl yaptı̆ı̆nı sorduğunuzda “arkadaşları ile maç yaparken birinci yarıda 5 golden 3'ünü; ikinci yarıda ise 3 golden 2'sini kendinin attğını, toplamda 
da 8 golden 5 'ini kendisinin atmış olduğunu" söylemiştir.

a. Sizce öğrenciniz bu işlemi yaparken nasıl düşünmüştür? b. Siz olsaydınız bu işlemin çözümünü öğrencinize nasıl anlatirsınız?

Bir öğrencinin yaptı̆̆ işlemin ve işlemle ilgili açıklamasının değerlendirilmesinin istendiği bu soruda öğretmen adaylarından beklenen; öğrenci açıklamasının ve işlem sonucunun doğru fakat açıklamanın işlemsel olarak gösteriminin hatalı olduğu, maç sırasında toplam atılan golün 8 gol, öğrencinin att̆ğı golün ise birinci yarıda 3 gol, ikinci yarıda 2 gol olduğu için maç sonucunda toplam atılan 8 golden 5 tanesinin öğrencinin attğını belirtmeleri, işlemi ise $\frac{3}{8}+\frac{2}{8}=\frac{5}{8}$ olarak göstermeleridir.

Bu soru için Öğretmen adaylarının cevapları 4 kategoriye ayrılmıştır. Aşağıda Tablo 2' de soru 3'e ait kategoriler ve örnek ÖA cevapları verilmiştir.

Tablo 2. Soru 3'e ait kategoriler ve örnek ÖA cevapları

\begin{tabular}{|c|c|c|}
\hline Kategoriler & ÖA & Örnek ÖA cevabı \\
\hline \multirow[t]{4}{*}{$\begin{array}{l}\text { Öğrenci düşüncesi yanlış, payda } \\
\text { eşitlemeli sonuç 19/15 olmalı. }\end{array}$} & ÖA3 & $\begin{array}{l}\text { "Öğrenci payları bir grup paydaları bir grup olarak gör- } \\
\text { müştür. Böyle düşünmesi normal fakat yanlıştır. Önce } \\
\text { ortak paydaya alır șekil üzerinde anlatırdım ve sonucu }\end{array}$ \\
\hline & ÖA4, & $\frac{3 \times 3}{15}+\frac{5 \times 2}{15}=\frac{19}{15}$ olarak buldurturdum."(ÖA7) \\
\hline & ÖA5 & \\
\hline & ÖA7 & \\
\hline $\begin{array}{l}\text { Öğrenci düşüncesi doğru, } \\
\text { payda eşitlenecek } \\
\text { değiştirilmeli. }\end{array}$ & ÖA6 & $\begin{array}{l}\text { "Böyle düşünmesi doğru fakat öğrenci aynı işlem üze- } \\
\text { rinde toplama yapılamayacağının farkında değildir. } \\
\text { Problemi paydaları eşit olacak bir problem olarak de- } \\
\text { ğiştirmesini sağlayıp sonucu } 15 / 19 \text { bulmasını sağla- } \\
\text { malıyız" }\end{array}$ \\
\hline Öğrenci düşüncesi yanlış. & ÖA1 & $\begin{array}{l}\text { "Gerçek yaşantısı ile bütünleştirerek düşünmüş basit } \\
\text { ve yanlış düşünmüş." }\end{array}$ \\
\hline
\end{tabular}

Öğretmen adaylarının hiçbiri doğru çözüm için gerekli olan anahtar kavramları açıklayamamıştır. ÖA1 öğrenciye bu problemi nasıl anlatacağı ile bir fikir yürütmemiş sadece öğrencinin basit ve yanlış düşündüğünü belirtmiştir. Beş öğretmen adayı sorunun ortak paydaya almamaktan kaynaklandığını belirtmişler, ortak payda kullanılması durumunda sonuç 19/15 olacağını, bu sonucun da oyundan elde edilen skor ile uyumlu olmayacağını göz ardı edip sadece işleme odaklanmışlar problem ve işlemin birlikte düşünememişlerdir. ÖA6 ise, problem ile işlemi birlikte düşünmüş fakat yine payda eşitleme fikri ile problemin; sonucun 19/15 olacak şekilde yeniden düzenlenmesi gerektiğini belirtmiştir. Öğretmen adaylarının öğrenci açıklamalarını kendi alan ve öğretim bilgileri bağlamında değerlendirme, bir işlemle ilgili uygun problem durumunu belirleme noktasında eksiklikleri olduğu söylenilebilir.

Soru 4: Ali'nin öğretmeni Ali'den $\frac{3}{4}$ ve $\frac{5}{6}$ kesirlerini şekil çizerek karşılaştırması istemiş̧tir. Ali'de aşağıdaki şekli çizmiş ve $\frac{3}{4}$ ve $\frac{5}{6}$ kesirlerinin aynı miktarı gösterdiğini söylemiştir. Sizce Ali'nin cevabı ile ilgili en uygun açıklama aşağıdakilerden hangisidir?
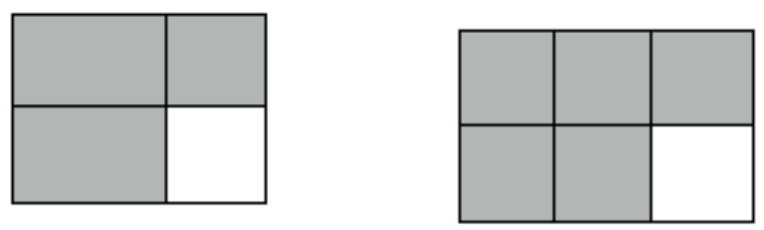

A) Ali iki şekilde de bir tane karenin kaldığını fark etmiştir.

B) Ali henüz ortak paydaya almayı bilmiyordur.

C) Ali $\frac{3}{4}$ kesrinin payına ve paydasına 2 ekleyerek kesrin $\frac{5}{6}$ olduğunu görmüştür.

| Kastamonu Eğitim Dergisi, 27(6), 2019| 
D) Tüm seçenekler uygun açıklama olabilir.

Bu soru kesirlerle karşılaştırma ve sıralama konusunda öğretmen adaylarının olası öğrenci cevaplarını tahmin edebilmelerine yönelik hazırlanmış çoktan seçmeli bir sorudur. A şıkkında $\frac{3}{4}$ ve $\frac{5}{6}$ kesirleri için Ali'nin çizdiği resme göre her iki şekilde de taranmamış bir kare kalmasından dolayı Ali'nin taralı olmayan kısımlara odaklanması ve sonucunda iki kesrin aynı miktarı gösterdiğini düşünmesine sebep olmuştur. B şıkkında Ali ortak paydaya almayı bilmediği için şekilleri payda eşitlemeden çizmiş ve böylece karşılaştrılabilir olmayan taranmış bölgeler üzerinde fikir yürüttüğü için iki kesrin aynı miktarı gösterdiğini söylemiş olma olasılığı mevcuttur. C şıkkında da Ali 3/4 kesrinin pay ve paydasına aynı sayıyı ekleyerek 5/6 kesrini elde etmiş, eşitliğin her iki tarafina aynı sayının eklenmesi eşitliği bozmaz düşüncesi ile bu durumu da doğal sayılarda işlemler gibi düşünmüş olabileceğinden bu cevap da uygun açıklama olabilir. $D$ şıkkı ise $A$, B, C şıklarının hepsinin Ali' nin düşüncesini olabileceğini önermektedir. Öğretmen adaylarından beklenen cevap tüm bu olası durumları düşünüp doğru şık olarak "D" şıkkını işaretlemeleridir.

Öğretmen adaylarından sadece ÖA5, D şıkkını doğru şık olarak işaretlemiş; diğer öğretmen adaylarının hepsi A şıkkını doğru şık olarak işaretlemişlerdir. B ve C şıklarındaki durumların olasılığını göz ardı etmişlerdir. Bu durum öğretmen adaylarının alan öğretim bilgileri kapsamında değerlendirilecek olursa; öğretmen adayları teorik bilgilerine dayanarak öğrencilerin kesirler konusundaki muhtemel düşüncelerini ve ne yapabileceklerini tahmin edebilme noktasında zorluk yaşamışlardır denilebilir.

Soru 5: Ayşe Öğretmenin sınıfi kesirleri karşılaştırma ve sıralama konusunda ortak paydaya alarak karşılaştırma yöntemini öğrenmişlerdir. Fakat Ayşe öğretmen kesirleri karşılaştırmada farklı yöntemlerin olabileceğini öğrencilerine fark ettirmek istemektedir. Buna göre;

a. Aşağıdaki kesir listelerinden hangisi Ayşe Öğretmenin bu amacını gerçekleştirmesine yardımcı olabilir.

$$
\begin{aligned}
& \text { a. } \frac{1}{4}, \frac{1}{20}, \frac{1}{2}, \frac{1}{13} \\
& \text { b. } \frac{4}{13}, \frac{3}{11}, \frac{6}{20}, \frac{1}{12} \\
& \text { c. } \frac{5}{6}, \frac{3}{8}, \frac{2}{3}, \frac{3}{7}
\end{aligned}
$$

d. Bu listelerin hepsi eşit derecede Ayşe öğretmenin amacını gerçekleştirmesine yardımcı olabilir.

\section{b. Cevabınızın sebebini açıklayınız.}

Kesir sayılarının karşılaştırılmasında farklı yöntemler kullanılabilir. Birincisi, bütün yarım gibi bir referans belirleyerek referans noktasına göre kesirleri karşılaştırmadır. Bir diğer yöntem birim kesirleri kullanarak karşılaştırma yapmaktır. Bu soruda öğrencilerine paydaları eşitleyerek paydaları eşit kesirlerin sıralama ve karşılaştırmasını öğrencilerine öğretmiş ve sıralama ve karşılaştırma ile ilgili bunun dışında farklı alternatif yollar arayan bir öğretmene uygun olabilecek kesir listeleri verilmiştir. A. Şıkkındaki kesir listesi birim kesirlerden oluşmaktadır ve Ayşe öğretmen için uygun bir modeldir. B ve $C$ şıklarındaki listelerde ise payları ya da paydaları eşit olmayan kesir listeleri mevcuttur. Payda eşitleyerek sıralama yapabilen öğrenciler için payların da eşitlenip sırlama yapılabileceği ve payları eşit kesirler için bir kural geliştirip genelleyebilmeleri bakımından bu şıklardaki listelerde Ayşe öğretmen için alternatif olabilir. Bu yüzden öğretmen adaylarından beklenen cevap D şıkkındaki " bu listelerin hepsi Ayşe öğretmenin amacını gerçekleştirmesine yardımcı olabilir"

\begin{tabular}{|c|c|c|}
\hline ÖA & Şık & Yaptığı Açıklama \\
\hline ÖA1 & A & "Paylarının1 olması sebebiyle karşılaştırma daha kolay yapılır" \\
\hline ÖA2 & $\mathrm{D}$ & "Paydaları eşitlememenin yanında paylarda eşitlenebilir. Bu sayede farkı bir sıralama yine gerçekleştirilebilir." \\
\hline ÖA3 & A & "Her bir kesrin tahtada alansal olarak gösterimini yapar ve bunların arasında karşılaştırma yapılabilir." \\
\hline ÖA4 & B & "6/20=3/10 olur. 3/10, 3/11, 1/12, 4/13 olur. Şeklinde paydaya bakılarak sıralama ve karşılaştırma yapılır." \\
\hline ÖA5 & A & "A şıkkında birim kesirler olduğundan amacı gerçekleştirmede yardımcı olabilir." \\
\hline ÖA6 & $A$ & $\begin{array}{l}\text { "Payları eşit olan kesirlerin paydalarının büyük olanlarının daha küçük bir kısmı kapsadığı için paydası en büyük olan en } \\
\text { küçük olacaktır." }\end{array}$ \\
\hline ÖA7 & $A$ & $\begin{array}{l}\text { "Payların eşit olduğu zaman nasıl kısa yoldan karşılaştırma yapılabileceği anlatılır. Payları eşit olduğunda paydası } \\
\text { küçük olan daha büyüktür." }\end{array}$ \\
\hline
\end{tabular}
cevabıdır. Öğretmen adaylarının işaretledikleri şık ve açıklamaları aşağıda Tablo 3’de verilmiştir.

\section{Tablo 3. Soru 5'e ait ÖA cevapları}


Tabloya bakıldığında sadece bir öğretmen adayının doğru cevabı verdiği görülmektedir. Bir öğretmen adayının da (ÖA4) B şıkkını seçtiği ve açıklama olarak da bir kesri sadeleştirip payı eşit iki kesir elde etmesi; payları eşit olanı kendi aralarında, sonrasında paydaya bakarak sıralama yapmayı önerdiği görülmektedir. Bunun dışında diğer öğretmen adaylarının hepsi A şıkkını seçmiş ve kendilerini bu şıkkı seçmeye yönelten sebep olarak da genellikle bu şıktaki kesir listesindeki kesirlerin birim kesir olmasından dolayı değil de paydaları eşit kesir gözüyle bakıp sıralamanın payları eşit kesirlerle yapılabileceğini önermişlerdir. Bu durum öğretmen adaylarının kesir öğretimini hangi sırada yapılabileceği ve öğretimi gerçekleştirmek için farklı alternatif yollar üretebilmelerinde eksiklik olduğunun göstergesi sayılabilir.

Soru 6:

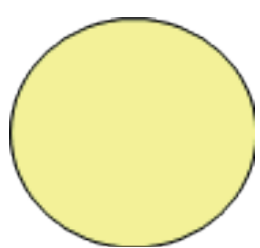

Yandaki şeklin;

a. $\frac{4}{5} \operatorname{inin} \frac{1^{\prime}}{8}$ ini bulunuz.

b. Bu işleme ait bir problem cümlesi yazınız.

Kesirli sayılardaki çarpma işlemi ve öğretimindeki çalışmalar iki grupta incelenebilir. Bunlar: bir tam sayının bir kesir ile çarpımı ve bir kesrin bir kesir ile çarpımı şeklindedir. Kesirlerle çarpma işleminin öğretimine bir doğal sayının bir kesirle çarpımı ile başlanır. Bunun nedeni çarpma işleminde doğal sayının kesir sayısının kaç defa tekrar ettiğini belirtmesidir. Bu durum öğrencinin daha önce öğrendiği çarpma işlemi ile ilişki kurmasını sağlar. Çarpmayı hep belli elemana sahip grupların yinelenmesi gibi bir sayı elde etmeye yarayan bir işlem olarak gören ve bu şekilde çarpmayı yineleme anlamıyla öğrenen öğrenciler, yineleme sonucunda elde edilen sayının çarpan ve çarpılandan daha büyük olacağı fikrini kesirli sayılarla çarpma işlemine genelleyebilirler. Bu ihtimalden dolayı kesirli sayılarla çarpma işleminin öğretiminde; kesirli sayılarla çarpma işleminin diğer anlamı olan bir kesrin başka bir kesir kadarının miktar olarak neye karşıı geldiği durumu üzerinde de durulmalıdır (Altun, 2005; Baykul, 2006). Bu soruda da kesirlerle çarpma işleminin bir kesrin başka bir kesir kadarının belirlenmesi anlamından yola çıkılarak öğretmen adaylarının bir bütünün $4 / 5^{\prime}$ inin $1 / 8^{\prime}$ ini bulurken yapacakları işlemin çarpma işlemi olarak matematik cümlesi ile ifade edip edemeyecekleri ve bu işlemi verilen model üzerinde gösterirken izleyecekleri yol incelenmek istenmiştir. Öğretmen adaylarının cevapları verilen işlemin çarpma işlemi olduğunu fark edip şekil üzerinde gösterebilmeleri ve işleme ait problem cümlesi olarak ifade edebilmelerine göre iki kategori $(\mathrm{K} 1, \mathrm{~K} 2)$ altnnda toplanmışttr. Bu kategoriler;

K1: Verilen işlemi bölme işlemi olarak algılama şekil üzerinde işlem sonucunu gösterememe fakat çarpma işlemine uygun problem cümlesi yazma.

K2: Çarpma işlemini yapıp şekil üzerinde gösterme, işleme uygun problem cümlesi yazma.

Yukarıdaki iki kategori için öğretmen adaylarının cevapları aşağıda Tablo 4’ te verilmiştir.

\section{Tablo 4. Soru 6'ya ait kategoriler ve ÖA cevapları}

\begin{tabular}{lll}
\hline Kategori & ÖA & Problem cümlesi \\
\hline & ÖA4 & $\frac{4}{5} \div \frac{1}{8}=\frac{32}{5}$ \\
& & b. "Ali amca bahçelerinin 4/5' ünü ağaçlandırmış. Bununda 1/8' ine kiraz fidanı dikmiştir. Ali amca bahçesinin \\
& ne kadarlık kısmına kiraz fidanı dikmiştir."
\end{tabular}

ÖA6 Bu işlem bir bölme işlemidir parça bütün ilişkisidir.

b. “Ayşe bir pastayı öncelikle 5 dilime ayırıp 4 dilimini kendisine alıyor. Aldığı dilimlerden kardeşine de vermeye karar verince elinde bulunan dilimleri 8 parçaya bölüp 1 dilimini veriyor. Ayşe kardeşine bütün pastadan ne kadar vermiştir?"

ÖA1

$\frac{4}{5} x \frac{1}{8}=\frac{4}{40}$ "Bunu şekil üzerinde göstermek zor. (sadeleştirmeyi düşünemiyor)

K2

Alinin 5 dilime ayrılmış bir pastası var. Ali bu beş dilimli pastanın 4 dilimini 8 eş parçaya ayırmıştır. Alinin 1 ÖA3 dilimi pastanın kaçta kaçıdır.(ÖA7)"

ÖA5 "Alinin doğum günü vardır. Ancak alinin babası o gün evde değildir. Ali babasını düşünerek pastanın 1/5'nini ayırmıştır. Geriye kalan parçalar 8 kişi arasında paylaşılacaktır. Burada Ali'nin kendisine geriye kalan

ÖA7 pastanın kaçta kaçı kalır. Bu 8 kişi arasında Ali'nin kendisi de vardır.(ÖA2)”

Tabloya bakıldığında iki öğretmen adayının çarpma işlemini bölme işlemi olarak algıladığı fakat problem cümlelerinin verilen işleme uygun olduğu görülmektedir. Bu iki öğretmen adayı dışındaki adaylar işlemi doğru algılamış. Şekil üzerinde $1 / 10$ cevabını göstermiş ve problemlerini de çarpma ișlemine uygun bir biçimde sonuç $1 / 10$ olacak șekilde | Kastamonu Eğitim Dergisi, 27(6), 2019| 
tasarlamışlardır. Tüm öğretmen adaylarının problemlerinde dikkat çekici olan sadece ÖA4 dışındaki diğer öğretmen adaylarının hepsi problemlerini bir doğum günü pastası üzerine kurgulamalarıdır. Ayrıca problemlerde kullandıkları kişi isimlerinin Ali ve Ayşe dışında başka isim olmamasıdır. Alan öğretim bilgisi açısından, öğretmen adaylarııı öğretim için seçecekleri problem, model ve benzeri araçların kullanımı konusunda sınırlı düşünce yapısına sahip oldukları düşünülebilir. Aynı zamanda çarpmaya ilişkin öğretim bilgileri de kısmen oluşmuştur denilebilir.

Soru 7: $\frac{7+5}{14+20}=$ ? Yandaki işlemin çözümü için verilmiş 3 çözüm yöntemi aşağıda sunulmuştur (Özmantar ve Bingölbali, 2009). Bu çözümlerden;

a. Hangilerinin doğru hangilerinin yanlış olduğunu düşünüyorsunuz ?

Ayşe'nin çözümü

$\frac{7+5}{14+20}=\frac{7+5}{14+20}=\frac{1+1}{2+4}=\frac{2}{6}=\frac{1}{3}$

Fatma'nın çözümü

$\frac{7+5}{14+20}=\frac{7}{14}+\frac{5}{20}=\frac{1}{2}+\frac{1}{4}=\frac{3}{4}$

Hayriye'nin çözümü

$\frac{7+5}{14+20}=\frac{7}{14+20}+\frac{5}{14+20}=\frac{7}{34}+\frac{5}{34}=\frac{12}{34}=\frac{6}{17}$

b. Doğru olmadığını düşündüğünüz çözüm(ler)le ilgili öğrenci hatasını lütfen belirtiniz.

Yukarıdaki soruda kesir işleminin üç farklı çözümünün öğretmen adayları tarafında doğruluğunun değerlendirilmesi ve varsa hatanın ne olduğunun açıklanması istenmiştir. Cevap olarak Ayşe, kesirli ifadede toplama işlemi bulunmasını göz ardı ederek sadeleştirme yaparak hatalı bir sonuca ulaşmıştır. Fatma, verilen kesirli ifadeyi iki kesrin toplamı şeklinde yazıp; kesirlerle toplama işlemi prosedürü uygulamış ve yanlış sonuca ulaşmıştı. Hayriye ise verilen ifadede paydaları sabit tutup payların toplamı olacak şekilde iki kesrin toplamı olarak yazmış ve doğru sonuca ulaşmıştı. Soru incelendiğinde Ayşe ve Fatma'nın işlemlerinin hatalı, Hayriye'nin doğru sonuca ulaşth̆̆ı görülebilir.

Bu soruda tüm öğretmen adayları Hayriye'nin cevabının doğru olduğunu belirterek doğru cevap vermiştir. Yanlış cevapların neden yanlış olduğu konusundaki açıklamaları da doğrudur. Öğretmen adaylarının, Ayşe ve Fatma'nın yanlış cevapları için yaptıkları açıklamalardan bazıları aşağıda verilmiştir.

ÖA2: "Ayşe pay ve paydadaki toplama işlemlerini gerçekleştirmeden sadeleştirme yapmış. Fatma payları doğru ayırmış fakat paydayı ayırmaması gerekiyordu. "

ÖA7: "7-14, 5-20 biribirinin kat olacağını düşünmüş ve sadeleştirme yoluna gitmiş ama aradaki toplama işlemini görmezden gelmiştir."

ÖA5: "Ayşenin çözümü yanlış çünkü payları ve paydaları bölmeye çalışmış, Fatmanında çözümü yanlış çünkü pay ve paydaları ayrı ayrı alıp toplamaya çalışmış."

Öğretmen adayları kesirlerle toplama işlemine hem alan bilgisi anlamında hem de öğrenci hatalarını belirleyebilmeleri bakımından hakimdir denilebilir.

KÖBS Soru 8'e Ait Bulgular

Soru 8: $\frac{4}{5}-\frac{3}{10}=$ ? işlemine ait; a. Bir problem kurunuz.

Kurduğunuz problemi model kullanarak çözünüz.

Kesirli sayılarla çıkarma işlemi ve öğretimindeki çalışmalar toplama öğretimindeki çalışmalara benzer şekilde yürütülür (Altun, 2005). Kesirli sayılarla çıkarma işlemi öğretiminde öncelikle iki kesir sayısının farkının yine bir kesir sayısı olduğu doğal sayılardaki gibi bu işlemlerle iki kesir sayısından üçüncü bir kesir sayısı elde edildiği vurgulanmalıdır. Bunun yanında bütün kesir sayıları ile çıkarma işlemi yapılamayacağı çıkarma işleminin yapılabilmesi için eksilenin çıkandan büyük olması gerektiği vurgulanmalıdır (Baykul, 2006). Paydası eşit olmayan kesir sayılarıyla çıkarma işleminin öğretiminde de kesir birimi kavramından yararlanıı.ı. Böyle bir çıkarma işleminde önce her iki kesre ait birim kesir sayıları ortak bir kesir birimiyle ifade edilip daha sonra paydaları eşit kesir sayılarıyla çıkarma işlemindeki gibi işlem yapılır 
(Baykul, 2006). Bu soruda öğretmen adaylarından beklenen verilen çıkarma işlemi ile çözülebilecek bir problem kurmaları ve kurdukları problemin çözümünü seçtikleri bir model üzerinde göstermeleridir. öğretmen adaylarının bu soruya verdikleri cevaplar iki kategoride $(\mathrm{K} 1, \mathrm{~K} 2)$ toplanmıştr. Cevapsız bırakılan soru ayrı bir kategoride değerlendirilmemiştir. Bu kategoriler;

K1: Verilen çıkarma işlemi çözülebilen bir problem kurma.

K2: Verilen çıkarma işlemine uygun olmayan bir problem kurma.

Aşağıda bu kategorilere göre sınıflanmış ÖA cevapları verilmiştir.

Cevapsız bırakan öğretmen adayları; ÖA1: Öğretmen adayı bu soru için problem kurma denemeleri yapmış fakat verilen işlemle uygun bulmadığı için silmiş ve bu soruyu cevapsız bırakmıştır. ÖA3: ÖA3'de ÖA1 gibi bu soru için problem kurma denemeleri yapmış fakat kağıdındaki silinmiş izlerden anlaşıldığı üzere soruyu boş bırakmayı tercih etmiş̧ir.

K1

ÖA2: "iki eşit pasta vardır. Bunlardan birini 5 parçaya bölüp 4 dilimini alıyoruz. Diğerini de 10 parçaya bölüp 3 dilimini alıyoruz. Aldığımız bu pasta dilimlerinden büyük olan küçük olandan ne kadar fazladır?"

ÖA4:"Bir varilin 4/5'ü su ile doludur. Bu varilden 3/10 kadar su boşaltırsa geride varilin kaçta kaçı su ile dolu kalır?"

ÖA6: “Aynı büyüklükteki pastalardan birini 5’e bölüp 4 parçasını alan Ali, diğer pastayı da 10'a bölüp 3 parçasını almıştır. Iki pastadan aldığı dilimleri karşılaştırdığında Ali nasıl bir fark görür?"

Yukarıda üç öğretmen adayının verilen işleme uygun problem durumu oluşturabildikleri görülmektedir. Öğretmen adayları sorunun ikinci şıkkı olan kurdukları problemi model üzerinde gösterme aşamasında da herhangi bir problem yaşamamışlardır. Fakat öğretmen adaylarının kesirlerle ilgili şemaları pasta paylaşımı üzerine kurulu olduğundan kurdukları problemler de birbirlerine benzemektedir. Var olan iki pastadan belli miktarlarda pasta dilimi alınması ve pasta dilimlerinin birinin diğerinden ne kadar daha fazla olduğunun bulunması şeklinde bir yol izlemişlerdir.

K2

ÖA5:"Ayşe 5 parçaya ayrılmış kumaşın önce 4 parçasını sonrada kalan kumaşun 3/10'unu kullanmıştır. Geriye ne kadar kumaş kalmıştr."

ÖA7: "Ayşe mozaik pastasının beşte dördünü yemiştir. Bunun arkasından kalan mozaik pastasının üçte onunu da yemiştir. Ayşe'nin ne kadar pastası kalmıştır."

Her iki öğretmen adayının da kurduğu problemler 1-[4/5+(1/5×3/10) ] işlemi ile çözülebilen problemlerdir ve cevabı $7 / 50$ dir. Bu öğretmen adayları işlemi model üzerinde göstermekte sıkıntı yaşamamışlar fakat kurdukları problemler çizdikleri modelin değil, verilen çıkarma işleminin modelidir.

\section{Sonuç ve Tartışma}

Bu çalışma temel olarak öğretmen adaylarının kesir öğretim bilgilerine yönelik bilgi verebilecek sorularla bir durum tespiti yapılmasını amaç edinmiştir. Bu amaç doğrultusunda verilerin toplanması ve analizi bölümünde tanıtilan ve sekiz sorudan oluşan KÖB soruları öğretmen adaylarına uygulanmıştr.

KÖBS birinci soru öğretmen adaylarının bir kesrin farklı anlamlarını bilme durumlarını değerlendiren bir sorudur. Bu sorudan elde edilen bulgular öğretmen adaylarının sadece kesrin oran anlamı ile ilgili doğru eşleştirmeyi yapabildiğini bunun dışında uygulamalarında hep kullandıkları parça bütün anlamını cümle içinde bir ifadede tespit etmede zorlandıkları görülmüştür. Bu durum sağlam bir kesir kavramının temelinin kesrin değişik anlamlarının öğrencide somutlaştrılması ile gerçekleşeceği (Olkun ve Toluk, 2006) düşüncesi çelişmektedir. Çünkü farklı anlamları henüz kendisinde somutlaştıramamış bir öğretmen adayının öğrencilerinde bu temeli oluşturmakta zorlanacağı aşikârdır. İkinci soru, birinci sorunun devamı niteliğinde olup kesir kavramının başlangıç noktası eş paylaştırma olduğu için öğretmen adaylarının eş olma, bütünün eş parçalara ayrılması kavramlarına ve matematik öğretim bilgisi bağlamında da öğrencilerinin bu konudaki yanılgılarını belirleyebilme durumları tespit edilmek istenmiştir. Bir öğretmen adayı hariç hepsi cevaplarında parça-bütün ilişkisi, eş parçalama kavramlarına vurgu yaparak açıklamalarını gerçekleştirmişlerdir. Öğretmenlerin kavramsal açıdan doğru modeller ve açıklamalar oluşturabilmeleri için kavramların ya da işlemlerin matematiksel anlamlarına hâkim olmaları gerektiği araştırmalarda vurgulanan bir konudur (Ma, 1999). Bu anlamda öğretmen adaylarının kesir öğretimini gerçekleştirebilmek için kesir öğretiminin başlangıç noktası olan kesrin farklı anlamlarını kavramsal olarak içselleştirmiş olmaları beklenmektedir. 
Üçüncü soruda öğretmen adaylarından kesirlerle toplama işlemi ile ilgili bir öğrenci açıklamasının ve işleminin değerlendirilmesi istenmiştir. Soruda öğretmen adaylarının hiçbirinin doğru çözüm için gerekli olan anahtar kavramları açıklayamadığı görülmüştür. Genelde birkaçı sorununun ortak paydaya almamaktan kaynaklandığını belirtmişleridir. Bu bağlamda öğretmen adaylarının öğrenci açıklamalarını kendi alan ve öğretim bilgileri ile değerlendirme, bir işlemle ilgili uygun problem durumunu belirleme noktasında eksiklikleri olduğu söylenilebilir. Bu bulgu Işık, Öcal ve Kar (2013) sınıf öğretmeni adaylarının beşinci sınıf öğrencilerinin kesirlerle toplama işlemine yönelik kurdukları problemlerdeki hataları belirleyebilmesi çalışmasındaki; öğretmen adaylarının parça bütün ilişkisini kuramaması bulgusu ile benzerlik göstermektedir. Hill, Ball ve Schilling (2007) öğretmenlerin sahip olması gereken matematiksel bilginin, öğrencilere açıklama yapma ve öğrenci cevaplarını değerlendirebilmelerine imkan tanıması gerektiğini belirtmiştir. Tam tersi bu soruda olduğu gibi öğretmen veya öğretmen adaylarının kesir işlemlerine yönelik pedagojik alan bilgilerini araştran çalışmalarda da (Aksu ve Konyalıoğlu, 2015; Işık, Kar, Işık ve Güler; 2012; Newton, 2008; Özmantar ve Bingölbali, 2009; Toluk Uçar, 2011; Ward ve Thomas; 2007) öğrenci hatalarını belirlemede, nedenlerini açıklamada öğretmen/öğretmen adaylarında eksiklikler olduğu tespit edilmiştir.

Dördüncü ve beşinci soru kesirlerin karşılaştrııması ve sıralanması ile ilgili olup; dördüncü soru kesirlerle karşılaştırma ve sıralama konusunda öğretmen adaylarının olası öğrenci cevaplarını tahmin edebilmelerine yönelik; beşinci soru ise kesirlerle karşılaştırma ve sıralama konusunda bir öğretmenin alternatif örnekleri kullanabilme durumunu sorgulayan çoktan seçmeli bir sorulardır. Bu sorulardan elde edilen bulgular, öğretmen adaylarının teorik bilgilerine dayanarak öğrencilerin kesirler konusundaki muhtemel düşüncelerini ve ne yapabileceklerini tahmin edebilme noktasında zorluk yaşadıklarını ve kesir öğretimini hangi sırada yapılabileceği ve öğretimi gerçekleştirmek için farklı alternatif yollar üretebilmelerinde sıkıntılar olduğunu göstermiştir.

Kesirli sayılarla çarpma işleminin diğer anlamı olan bir kesrin başka bir kesir kadarının miktar olarak neye karşııı geldiği durumu üzerinde de durulması (Altun, 2005; Baykul, 2006) gereken konulardan biridir. Altnncı soruda, kesirlerle çarpma işleminin bir kesrin başka bir kesir kadarının belirlenmesi anlamından yola çıkılarak öğretmen adaylarının bir bütünün $4 / 5^{\prime}$ inin $1 / 8^{\prime}$ ini bulurken yapacakları işlemin çarpma işlemi olarak matematik cümlesi ile ifade edip edemeyecekleri ve bu işlemi verilen model üzerinde gösterme durumlarını incelenmiştir. Elde edilen bulgularda iki öğretmen adayının verilen ifadedeki işlemi bölme işlemi gibi algıladıkları, bazılarının işlemin sonucuna uygun problemlerini oluşturduğu, bazı öğretmen adaylarının ise öğretim için seçecekleri problem, model ve benzeri araçların kullanımı konusunda sınırlı düşünce yapısına sahip olduklarına yer verilmiştir. Bu bulgular, basit kesirlerin çarpımına yönelik problem kurma sürecinde başlangıçta alınan bütün veya çokluğa birinci kesri uyguladıktan sonra oluşan yeni kısma ikinci kesir sayısının uygulanmasını gerektiren ifadeyi problem cümlesi olarak belirtemedikleri ve çarpımdaki işlemi değil çarpım sonucunda oluşan kesri bulmaya yönelik problemler kurdukları Işık'ın (2011) çalışmasıyla ve öğretmen adaylarının kesirlerle çarpma konusunda kavramsal açıdan bilgilerinin yeterince derin olmadığı yönü ile de Işıksalın (2006) çalışması ile benzerlikler göstermektedir.

Yedinci soruda öğretmen adaylarından kesir işleminin sunulan üç farklı çözümünde bulunan hataların değerlendirilmesi ve hataların neler olduğunu açıklamaları istenmiştir. Bu soruda tüm öğretmen adayları doğru cevabı tespit ederek uygun açıklamalar yapmışlardır. Yanlış cevapların neden yanlış olduğu konusundaki açıklamaları da doğrudur. Bu sorunun sınıf öğretmenlerine yöneltilmesi sonucunda Özmantar ve Bingölbali (2009) çalışmalarında farklı sonuçlara ulaşmışlar ve sınıf öğretmeni olarak görev yapan katılımcıların azımsanamayacak bir kısmında bu soru dolayısıyla payda eşitleme sadeleştirme, kesirlerde toplama ve ortak payda kavramları ile ilgili yanılgılara ve zorluklara sahip olduklarına bulgularında yer vermişlerdir. İki araştırmadaki iki farklı sonucun sebebi Özmantar ve Bingölbali'nin (2009) çalışmalarını çok fazla sayıda öğretmenle yürütmeleri ve çalışma gruplarındaki öğretmenlerin eğitim fakültesi mezunu olmayıp farklı alanlardan gelmeleri olarak düşünülebilir.

Sekizinci ve son soruda öğretmen adaylarının verilen çıkarma işlemi ile çözülebilecek bir problem kurmaları ve kurdukları problemin çözümünü seçtikleri bir model üzerinde göstermeleri beklenmektedir. Elde edilen bulgularda iki öğretmen adayının soru için uğraştıkları fakat sonrasında silip soruyu cevapsız bıraktıkları, üç öğretmen adayının işleme uygun problem kurabildikleri, iki öğretmen adayının ise başka bir işlemle çözülebilen bir problem kurdukları, problem kurma dışında verilen işlemin model üzerinde gösteriminde ise hiçbir öğretmen adayının sorun yaşamadığı tespit edilmiştir. Bu bulgular altıncı sorudakine benzer şekilde yorumlanabilir. Öğretmen adayları kesirlerle işlemler konusunda işlemsel prosedürleri takip etmekte zorlanmamakta fakat kavramsal olarak sıkıntılar yaşamaktadırlar.

Sonuçta; öğretmen adaylarının kesirlerle işlemler ve problem kurma, kesrin farklı anlamları, işlemsel ve kavramsal sorulara uygun yanıtlar verebilme, öğrencilerin kesirler konusundaki muhtemel düşüncelerini tahmin edebilme noktasında sıkıntılar yaşadığını göstermektedir. Öğretmen adayları ve öğretmenlerle yapılan çalışmalarda kesirler konusunda (Eroğlu, 2012; Işık, 2011; Işıksal, 2006; Gökkurt, Soylu ve Demir, 2015; Gökkurt, Şahin, Soylu ve Soylu, 2013; Kar ve 
Işık, 2015; Ward, 2009; Ward ve Thomas, 2007) benzer sonuçlara ulaşılması; öğretmen adaylarının bu konudaki alan ve alan öğretim bilgilerinin geliştirilmesi, teori ve pratik arasındaki boşluğun doldurulması yanılgıların ve eksikliklerin giderilmesi gerektiğine işaret etmektedir.

\section{Kaynakça}

Akbaba Dağ, S. (2009). Sınıf öğretmeni adaylarııın temel matematik I-II derslerine ilişkin kavram yanılgılarının incelenmesi. (Yayınlanmamış yüksek lisans tezi). Gazi Üniversitesi Eğitim Bilimleri Enstitüsü, Ankara.

Aksu, M. (1997). Student performance in dealing with fractions. The Journal of Educational Research, 90(6), 375-380.

Altun, M. (2005). Matematik öğretimi. Bursa: Alfa Aktüel Yayın Dağıtım.

Aksu, Z. \& Konyalığlu, A. C. (2015). Sınıf öğretmeni adaylarının kesirler konusundaki pedagojik alan bilgisi. K. Ü Kastamonu Eğitim Dergisi. 23(2), 723-738.

Alacacı, C. (2009). Öğrencilerin kesirler konusundaki kavram yanılgıları. İçinde E. Bingölbali \& M.F. Özmantar (Ed.) Matematiksel zorluklar ve çözüm önerileri (s. 63-95). Ankara: Pegem Akademi.

Başgün, M. \& Ersoy, Y. (2000). Sayılar ve aritmetik I: Kesir ve ondalık sayıların öğretilmesinde bazı güçlükler ve yanılgılar. İçinde, IV. Fen Bilimleri Eğitimi Kongresi Bildiri Kitabı: (s. 604-608), Ankara: MEB.

Baykul, Y. (2006). illköğretimde matematik öğretimi (1.-5. Sınıflar). Ankara: Pegem Akademi.

Behr, M., Harel, G., Post, T., \& Lesh, R. (1992). Rational number, ratio, proportion. In D. A. Grouws (Ed.), Handbook of Research on Mathematics Teaching and Learning (pp. 296-333). New York: Macmillan Publishing.

Cramer, K., \& Henry, A. (2002). Using manipulative model to build number sense for addition of fractions. In B. Litwiller (Eds.), Making sense of fractions, ratios and proportions (pp. 41-48). Reston, VA: NCTM.

Cramer, K., Post, T., \& delMas, R. (2002). Initial fraction learning by fourth- and fifth-grade students: A comparison of the effects of using commercial curricula with the effects of using the Rational Number Project curriculum. Journal for Research in Mathematics Education, 33(2), 111- 144.

Çepni, S. (2012). Araştırma ve proje çalışmalarına giriş. Trabzon: Celepler Matbaacılık.

Doğan Temur, Ö. (2011). Dördüncü ve beşinci sınıf öğretmenlerinin kesir öğretimine ilişkin görüşleri: Fenomenografik araştırma. Dumlupınar Üniversitesi Sosyal Bilimler Dergisi. 29, 203-212.

Eroğlu, D. (2012). Examining prospective elementary mathematics teachers' knowledge about students' mistakes related to fractions (Unpublished master dissertation). Middle East Technical University, Social Sciences Institute, Ankara.

Gökkurt, B., Soylu, Y. \& Demir, Ö. (2015). Ortaokul matematik öğretmenlerinin kesirlerin öğretimine yönelik görüşlerinin incelenmesi. Necatibey Eğitim Fakültesi Elektronik Fen ve Matematik Eğitimi Dergisi, 9(2), 230-251.

Gökkurt, B., Şahin, Ö. \& Soylu, Y. (2012). Matematik öğretmenlerinin matematiksel alan bilgileri ile pedagojik alan bilgileri arasındaki ilişkinin incelenmesi. The Journal of Academic Social Science Studies, 5(8), 997-1012.

Gökkurt, B., Şahin, Ö., Soylu, Y. \& Soylu, C. (2013). Öğretmen adaylarının kesirlerle ilgili pedagojik alan bilgilerinin öğrenci hataları açısından incelenmesi. International Online Journal of Educational Sciences, 5(3), 719-735.

Haser, Ç.\& Ubuz, B. (2001). Illköğretim 5. sınıf öğrencilerinin kesirler konusunda kavramsal anlama ve işlem yapma performansı. İçinde, IV. Fen Bilimleri Eğitimi Kongresi Bildiri Kitabı. (s. 609-612), Ankara: MEB Yayınları.

Hassemann, K. (1981). On difficulties with fractions. Educational Studies in Mathematics, 12(1), 71-87.

Hill, H, C., Ball, D. L., \& Schilling, S. G. (2007). Unpacking 'pedagogical content knowledge': Conceptualizing and measuring teachers' topic and specific knowledge of students. Journal for Research in Mathematics Education. 39(4), 372-400.

Işık, C., Kar, T., Işık, A. \& Güler, G. (2012). illköğretim matematik öğretmeni adaylarııı kesirlerde toplama işlemine yönelik kurulan problemlerdeki hataları belirleyebilme becerileri. Turkish Journal of Computer and Mathematics Education, 3(3), 161-182.

Işık, C. (2011). Il lköğretim matematik öğretmeni adaylarııın kesirlerde çarpma ve bölmeye yönelik kurdukları problemlerin kavramsal analizi. Hacettepe Üniversitesi Eğitim Fakültesi Dergisi, 41, 231-243.

Işıksal, M. (2006). A study on pre-service elementary mathematics teachers' subject matter knowledge and pedagogical content knowledge regarding the multiplication and division of fractions (Unpublished doctoral dissertation), Middle East Technical University, Social Sciences Institute, Ankara.

Işık, C., Öcal, T. \& Kar, T. (2013). Analysis of pre-service elemantary teachers' pedagogical content knowledge in the context of problem posing. Paper presented at the meeting of Eight Congress of European Research in Mathematics Education (CERME 8), Antalya, Turkey.

Kar, T. \& Işık, A. (2015). Ortaokul matematik öğretmenlerinin kesirlerle çıkarma işlemine yönelik problem kurma becerilerinin incelenmesi. Dicle Üniversitesi Ziya Gökalp Eğitim Fakültesi Dergisi, 24, 243-276.

$\mathrm{Ma}$, L. (1999). Knowing and teaching elementary mathematics: Teachers' understanding of fundamental mathematics in China and the United States. Mahwah, NJ: Erlbaum.

Moss, J., \& Case, R. (1999). Developing children's understanding of the rational numbers: A new model and an experimental curriculum. Journal for Research in Mathematics Education, 30(2), 122-147.

Olkun, S.\& Toluk Uçar, Z. (2006). ilköğretimde matematik öğretimine çağdaş yaklaşımlar. Ankara: Ekinoks.

Özmantar, M. F. \& Bingölbali, E. (2009). Sınıf öğretmenleri ve matematiksel zorlukları. Gaziantep Üniversitesi Sosyal Bilimler Dergisi, $8(2), 401-427$

|Kastamonu Eğitim Dergisi, 27(6), 2019| 
Toluk Uçar, Z. (2011). Öğretmen adaylarının pedagojik içerik bilgisi: Öğretimsel açıklamalar. Turkish Journal of Computer and Mathematics Education, 2(2), 87-102.

Siebert, D., \& Gaskin, N. (2006). Creating, naming and justifying fractions. Teaching Children Mathematics, 12(8), $394-400$.

Yıldırım, A. \& Şimşek, H. (2008). Sosyal bilimlerde nitel araştırma yöntemleri, Ankara: Seçkin Yayıncılık.

Walle de Van J., Karp, S. K., \& Bay-Williams J. (2013). ilkokul ve ortaokul matematiği. (Çev. S. Durmuş). Ankara: Nobel Yayın Dağıtım. Ward, J., \& Thomas, G. (2007). What do teachers know about fractions? in findings from the New Zealand numeracy development projects (pp. 128-138). Wellington, New Zealand: Learning Media.

Ward, J. (2009). Teacher knowledge of fractions: An assessment. (Unpublished doctoral dissertation). Otago University, Dunedin, New Zealand. 